PSYCHOLOGIA ROZWOJOWA, $2020 *$ tom 25 , nr 2, s. 31-42

doi:10.4467/20843879PR.20.010.12265

www.ejournals.eu/Psychologia-Rozwojowa

KAROLINA APPELT (iD 0000-0003-3106-8959

Wydział Psychologii i Kognitywistyki Uniwersytet im. Adama Mickiewicza w Poznaniu Faculty of Psychology and Cognitive Sciences Adam Mickiewicz University in Poznań e-mail: karolina.appelt@amu.edu.pl

MARTA JARZEMBOWSKA

Wydział Psychologii i Kognitywistyki Uniwersytet im. Adama Mickiewicza w Poznaniu Faculty of Psychology and Cognitive Sciences Adam Mickiewicz University in Poznań e-mail: martajarzembowska@interia.pl

\title{
Aktywność twórcza a korzystanie z urządzeń ekranowych przez dzieci w wieku przedszkolnym
}

\section{Creative Activity and the Use of Multimedia Devices by Children at Preschool Age}

\begin{abstract}
The article presents the results of own research whose purpose was to answer the question whether screen time is related to the level of creative activity of preschool children. The relationship between creative activity and the possession of electronic devices by preschool children was also examined. 32 children aged 5 years and 1 month to 6 years and 11 months and their parents took part in the research conducted in 2018. The research tools used were: (1) The Test for Creative Thinking - Drawing Production (TCT-DP) Form A of Urban and Jellen (1996) in the Polish adaptation of Matczak, Jaworowska, Stańczak (2000), (2) Questionnaire for parents and teachers: How creative is the child? and (3) Questionnaire regarding the use of multimedia devices by preschool children. The obtained results indicate a relationship between screen time and the level of creative activity of preschool children. Studies show that the amount of free time spent with a multimedia device by a child after returning from kindergarten correlates negatively with the various dimensions of creative thinking. Children who more often play without using multimedia devices show greater creative ability manifested in the child's basic forms of activity during this period: play, art and language activities.
\end{abstract}

Keywords: creative thinking, creative activity, multimedia devices, preschool age, development, screen time

Słowa kluczowe: myślenie twórcze, aktywność twórcza, urządzenia ekranowe, wiek przedszkolny, rozwój, czas przed ekranem 


\section{WPROWADZENIE}

Szybki rozwój technologii informacyjno-komunikacyjnych (TIK) oraz powszechny dostęp do urządzeń multimedialnych sytuują multimedia w grupie istotnych czynników wpływających współcześnie na rozwój dzieci (Chassiakos $\mathrm{i}$ in., 2016; Mullan, 2017; Booker, Kelly, Sacker, 2018). Nadmierne korzystanie z tego typu urządzeń nie tylko znacząco oddziałuje na rozwój w sferze fizycznej, poznawczej, emocjonalnej i społecznej w okresie dzieciństwa, ale ma także swoje długofalowe konsekwencje (Przybysz-Zaremba, 2008; Pagani i in., 2016; Simonato i in., 2018). TIK są w stanie przyspieszyć procesy edukacyjne, służąc jako narzędzie szybkiej komunikacji oraz otwierając dostęp do ogromnych zasobów wiedzy i informacji. Zaniedbania wynikające $\mathrm{z}$ niewłaściwego, w tym często nadmiernego, wykorzystania TIK moga jednak prowadzić do uzależnienia oraz zaburzeń rozwoju w sferze motorycznej, emocjonalnej, społecznej i poznawczej (m.in. Przybylski, 2014; Przybylski i in., 2014; Peper, Harvey, 2018). Zbyt wczesny dostęp do tabletów i smartfonów skutkuje: wadami postawy (tzw. smartfonowy kark), opóźnieniami rozwoju mowy, zaburzeniami koncentracji uwagi, osłabieniem motoryki małej, problemami ze snem i wyciszeniem się, zaburzeniami emocjonalnymi, trudnościami w budowaniu relacji społecznych poza światem wirtualnym (m.in. Szpunar, 2004; Przybylski $\mathrm{i}$ in., 2016; LeBourgeois i in., 2017; Celis-Morales $i$ in., 2018). Treści audiowizualne ograniczają wyobraźnię dziecka, dając gotowe wytwory w postaci obrazów i dźwięków, nie pozostawiając miejsca na własną interpretację i kreatywność (por. Appelt, 2009). Choć oglądanie niektórych programów w telewizji czy emisja wartościowej bajki z telefonu mogą wpływać pozytywnie na pobudzenie dziecięcej wyobraźni, to jednak nadmierne korzystanie z urządzeń multimedialnych nie rozwija zdolności twórczych, a raczej sprzyja ich ograniczeniu (Granic, Lobel, Engels, 2013).

Problematyka poruszana $\mathrm{w}$ niniejszym artykule dotyczy oddziaływania urządzeń ekranowych na twórcze myślenie dziecka w wieku przedszkolnym, które przekłada się na jego codzienną aktywność. Współczesne dzieci od najmłodszych lat korzystają z urządzeń elektronicznych, bawiąc się zabawkami, które wydają dźwięki i dają efekty świetlne, oglądając telewizję czy wpatrując się w zmieniające się kolorowe ekrany smartfonów. Urządzenia multimedialne są powszechnie obecne w codzienności, zarówno dzieci szkolnych, jak i tych młodszych, które dopiero zaczęły edukację przedszkolną, a coraz częściej w świat tak zwanych nowoczesnych technologii wchodzą już maluchy w okresie wczesnego dzieciństwa (por. Appelt, 2015). Częstym widokiem w restauracjach, wśród podróżujących samochodami, pociągami czy czekających w poczekalniach lekarskich, są dzieci wraz z rodzicami wpatrzone w ekrany smartfonów bądź tabletów. Eksperyment Jenny S. Radesky, pediatry zajmującej się rozwojem behawioralnym w Boston Medical Center, podczas obserwacji 55 rodzin w restauracjach wykazał, że w 40 przypadkach rodzice korzystali ze smartfonu, z czego większość przez cały czas trwania posiłku (Radesky i in., 2016). Dzieci powielają zachowania dorosłych, naśladując pewien model sposobu bycia w różnych sytuacjach. Brak dojrzałej postawy i świadomości rodzica dotyczącej konsekwencji nadużywania mediów ekranowych może skutkować negatywnie w różnych obszarach rozwoju dziecka. Nasuwają się więc pytania: Czy przyzwalanie dzieciom na korzystanie z urządzeń ekranowych na tak wczesnym etapie rozwoju to odpowiednia i bezpieczna forma aktywności? Czy umysł stymulowany błyskiem obrazów, wielością dźwięków i natłokiem informacji będzie zdolny myśleć twórczo? Tak powszechny dostęp dzieci do urządzeń elektronicznych skłania do podjęcia badań nad jego następstwami psychologicznymi dla rozwoju dziecka (Brzezińska, Appelt, Ziółkowska, 2016). Dotychczasowe badania pokazują, że poziom myślenia twórczego spada $\mathrm{z}$ biegiem lat, a odpowiednia stymulacja lub jej brak ma istotny wpływ na poziom aktywności twórczej. Wyniki badań wskazują, że częste przesiadywanie dziecka przed ekranem telewizora wpływa niekorzystnie zarówno na sferę twórczości werbalnej, jak i niewerbalnej (Peterson, Peterson, Carroll, 1987, za: Kubicka, 2007a). W zaprezentowanych niżej badaniach podjęto próbę zweryfikowania hipotez mówią- 
cych o związku między czasem korzystania z urządzeń ekranowych przez dzieci w wieku przedszkolnym a poziomem ich twórczego myślenia. Podjęto także analizę tego, czy istotne jest, z jakiego typu urządzenia dziecko korzysta i czy posiada je do własnej dyspozycji (Jarzembowska, 2018).

\section{PROBLEM}

\section{Cel badań i hipotezy badawcze}

Celem badań były odpowiedzi na pytania: Czy między grupami dzieci przedszkolnych korzystających z różnych urządzeń ekranowych (telewizor, smartfon, tablet/komputer) istnieje różnica w natężeniu aktywności twórczej? oraz Czy posiadanie przez dziecko przedszkolne własnego urządzenia multimedialnego ma związek z poziomem myślenia twórczego? Poszukiwałyśmy także odpowiedzi na pytania o związek między ilością czasu spędzanego przed ekranem urządzeń multimedialnych a aktywnością twórczą dzieci przedszkolnych.

Analiza literatury dotyczącej mediów ekranowych oraz twórczego myślenia ujawniającego się w twórczej aktywności dziecka pozawalają na postawienie następujących hipotez:

(H1) Istnieje różnica między grupami dzieci przedszkolnych korzystających z różnych urządzeń ekranowych (telewizor, smartfon, tablet/ komputer) w natężeniu myślenia twórczego oraz aktywności twórczej.

(H2) Istnieje różnica między natężeniem myślenia twórczego oraz poziomem aktywności twórczej u dzieci przedszkolnych posiadających własne urządzenie ekranowe a grupą dzieci, które takiego urządzenia na własność nie posiadają.

(H3) Istnieje związek między długością czasu spędzanego przed ekranem urządzeń multimedialnych przez dzieci w wieku przedszkolnym a ich myśleniem oraz aktywnością twórczą.

Przy czym myślenie twórcze rozumiemy jako takie, które według modelu Klausa K. Urbana $(1991 ; 2005)$ zakłada istnienie sześciu grup komponentów twórczości, które można pojmować jako predyspozycje twórcze. Wszystkie są wzajemnie powiązane i razem tworzą system, uruchamiający proces twórczy. Trzy pierwsze grupy to składniki poznawcze, to jest: (1) myślenie dywergencyjne, które charakteryzuje: płynność - łatwość wytwarzania pomysłów, giętkość - gotowość do zmiany kierunku myślenia, oraz oryginalność - zdolność do wytwarzania reakcji nietypowych, niezwykłych, niepowtarzalnych; (2) kompetencje ogólne, rozumiane jako umiejętność rozumowania analizowania i syntetyzowania; (3) specyficzna wiedza i specyficzne umiejętności niezbędne w obszarach twórczego myślenia i działania. Trzy kolejne komponenty to: (4) zaangażowanie zadaniowe; (5) motywy sprzyjające twórczości, to jest: potrzeba nowości, pęd do wiedzy, ciekawość, potrzeba sprawstwa, samoaktualizacji, podejmowanie odpowiedzialności, gotowość do zabawy; (6) tolerancja wieloznaczności jako: otwartość na doświadczenia, gotowość podejmowania ryzyka, nonkonformizm. Aktywność twórcza to natomiast działanie, które w toku uaktywnienia myślenia twórczego prowadzi do wytworzenia czegoś nowego, fascynującego i odkrywczego. W wieku przedszkolnym aktywność twórcza obejmuje trzy podstawowe formy działalności dziecka: zabawę, twórczość plastyczną i twórczość językową.

\section{METODA}

\section{Grupa badana}

Badania zostały przeprowadzone w dwóch grupach dzieci uczęszczających do przedszkola. Pierwsza grupa badana liczyła 13 dzieci w wieku od 5 lat i 11 miesięcy do 6 lat i 11 miesięcy. Druga zaś obejmowała 19 dzieci w wieku od 5 lat i 1 miesiąca do 6 lat i 11 miesięcy. Razem przebadano 32 dzieci oraz 30 rodziców. Dwoje rodziców nie wypełniło ankiet, zatem w badaniach wzięło udział 30 par dziecko-rodzic. Grupa badanych rodziców liczyła 19 matek i 12 ojców z wykształceniem wyższym, 7 matek i 10 ojców z wykształceniem średnim, 3 matki i 6 ojców z wykształceniem zawodowym oraz 1 matka i 2 ojców z wykształceniem podstawowym. W tabeli 1 zilustrowano charakterystykę badanej grupy dzieci, także z podziałem na dziewczynki 
Tabela 1. Charakterystyka grupy badanej

\begin{tabular}{|c|c|c|c|}
\hline Zmienne & $\begin{array}{l}\text { Dziewczynki } \\
\quad \mathbf{N}=17\end{array}$ & $\begin{array}{l}\text { Chlopcy } \\
\mathrm{N}=13\end{array}$ & $\begin{array}{l}\text { Ogólem } \\
\mathbf{N}=\mathbf{3 0}\end{array}$ \\
\hline \multicolumn{4}{|l|}{ Wiek dziecka } \\
\hline Średnia & 6.09 & 6.35 & 6.20 \\
\hline Odchylenie standardowe & .51 & .43 & .49 \\
\hline Minimum & 5.00 & 6.00 & 5.00 \\
\hline Maksimum & 7.00 & 7.00 & 7.00 \\
\hline \multicolumn{4}{|l|}{ Posiadanie rodzeństwa } \\
\hline Tak & $12(70.6 \%)$ & $8(61.5 \%)$ & $20(66.7 \%)$ \\
\hline Nie & $5(29.4 \%)$ & $5(38.5 \%)$ & $10(33.3 \%)$ \\
\hline \multicolumn{4}{|l|}{ Posiadanie rodzeństwa } \\
\hline Starsze & $7(41.2 \%)$ & $4(30.8 \%)$ & $11(36.7 \%)$ \\
\hline Młodsze & $3(17.6 \%)$ & $3(23.1 \%)$ & $6(20 \%)$ \\
\hline Starsze i młodsze & $2(11.8 \%)$ & $1(7.7 \%)$ & $3(10 \%)$ \\
\hline \multicolumn{4}{|l|}{ Wykształcenie matki } \\
\hline Podstawowe & $1(5.9 \%)$ & $0(0 \%)$ & $1(3.3 \%)$ \\
\hline Zawodowe & $2(11.8 \%)$ & $1(7.7 \%)$ & $3(10 \%)$ \\
\hline Średnie & $4(23.5 \%)$ & $3(23.1 \%)$ & $7(23.3 \%)$ \\
\hline Wyższe & $10(58.8 \%)$ & $9(69.2 \%)$ & $19(63.3 \%)$ \\
\hline \multicolumn{4}{|l|}{ Wykształcenie ojca } \\
\hline Podstawowe & $2(11.8 \%)$ & $0(0 \%)$ & $2(6.7 \%)$ \\
\hline Zawodowe & $2(11.8 \%)$ & $4(30.8 \%)$ & $6(20 \%)$ \\
\hline Średnie & $5(29.4 \%)$ & $5(38.5 \%)$ & $10(33.3 \%)$ \\
\hline Wyższe & $8(74.1 \%)$ & $4(30.8 \%)$ & $12(40 \%)$ \\
\hline \multicolumn{4}{|l|}{ Posiadanie własnego urządzenia ekranowego przez dziecko } \\
\hline Telefon/smartfon & $3(17.6 \%)$ & $1(7.7 \%)$ & $4(13.3 \%)$ \\
\hline Tablet & $4(23.5 \%)$ & $3(23.1 \%)$ & $7(23.2 \%)$ \\
\hline Telewizor w swoim pokoju & $6(35.3 \%)$ & $3(23.1 \%)$ & $9(30 \%)$ \\
\hline Nie ma & $8(47.1 \%)$ & $7(53.8 \%)$ & $15(50 \%)$ \\
\hline \multicolumn{4}{|l|}{ Korzystanie z urządzeń ekranowych w towarzystwie dorosłego } \\
\hline Przeważnie samo & $7(41.2 \%)$ & $7(53.8 \%)$ & $14(46.7 \%)$ \\
\hline Często w towarzystwie dorosłego & $8(47.1 \%)$ & $6(46.2 \%)$ & $14(46.7 \%)$ \\
\hline Zawsze w towarzystwie dorosłego & $2(11.8 \%)$ & $0(0 \%)$ & $2(6.7 \%)$ \\
\hline \multicolumn{4}{|l|}{ Cel i warunki korzystania z urządzeń ekranowych } \\
\hline Gra w gry & $2(11.8 \%)$ & $6(46.2 \%)$ & $8(26.7 \%)$ \\
\hline Ogląda filmiki, bajki & $8(47.1 \%)$ & $9(69.2 \%)$ & $17(56.7 \%)$ \\
\hline Nie korzysta w ogóle & $2(11.8 \%)$ & $1(7.7 \%)$ & $3(10 \%)$ \\
\hline Dziecko korzysta pod ścisłą kontrolą dorosłego & $9(52.9 \%)$ & $6(46.2 \%)$ & $15(50 \%)$ \\
\hline $\begin{array}{l}\text { Dziecko samo obsługuje urządzenie, dorosły nie kontroluje co } \\
\text { ogląda }\end{array}$ & $0(0 \%)$ & $0(0 \%)$ & $0(0 \%)$ \\
\hline
\end{tabular}

Źródło: opracowanie własne. 
i chłopców. Porównanie tych grup nie jest przedmiotem analizy w niniejszym artykule, ale również może prowadzić do ciekawych wniosków.

\section{Charakterystyka narzędzi badawczych}

W badaniu zastosowano zestaw trzech narzędzi badawczych: (1) Rysunkowy Test Twórczego Myślenia TCT-DP w wersji A; (2) Kwestionariusz dla rodziców i nauczycieli: Jak twórcze jest dziecko? oraz (3) Kwestionariusz korzystania z urządzeń multimedialnych przez dzieci w wieku przedszkolnym.

Do oceny poziomu twórczego myślenia u dzieci wykorzystano Rysunkowy Test Twórczego Myślenia TCT-DP Klausa K. Urbana i Hansa G. Jellena (1996) w polskiej adaptacji Anny Matczak, Aleksandry Jaworowskiej, Joanny Stańczak (2000). Założenia teoretyczne testu nawiązują do koncepcji twórczości Urbana (1991; 2005) i uwzględniają różne komponenty twórczości, zarówno natury poznawczej, jak i osobowościowej. Test wykorzystywany jest do badań przesiewowych, służących wykrywaniu osób stosunkowo najbardziej lub/i najmniej twórczych, począwszy od 5. roku życia. Autorzy testu sugerują też wykorzystywanie go przy ocenie skuteczności treningów twórczości, zatem test nie tylko służy do oceny predyspozycji wrodzonych, ale również tych zależnych od środowiska i procesu uczenia się.

$\mathrm{Na}$ arkuszu znajduje się ramka, w której widnieje 5 elementów: półkole, linia krzywa, linia łamana, linia przerywana oraz punkt. Poza ramą znajduje się otwarty kwadrat. Rama pełni istotną funkcję, dając osobie badanej możliwość przekroczenia wyznaczonych granic rysunku, sugerowaną w sposób pośredni przez kwadrat poza ramą, oraz możliwość przekroczenia granic w pełni z własnej inicjatywy. Test ma dwie wersje - A i B, które różnią się usytuowaniem elementów graficznych. W wersji B elementy są odwrócone o 180 stopni w stosunku do badanego. W badaniu zastosowano wersję A. Zadaniem badanego dziecka było dokończenie rysunku w dowolny sposób, według własnego pomysłu, oraz - opcjonalnie - nadanie mu tytułu. Po podaniu instrukcji badający notował czas rozpoczęcia rysowania oraz czas zakończenia. Czas wykony- wania rysunku wynosił maksymalnie 15 minut i brany był pod uwagę przy ocenie.

Ocena testu jest zobiektywizowana, ponieważ uwzględnia wiele różnych wyznaczników procesu twórczego: poznawczych, osobowościowych oraz środowiskowych. Dokonuje się jej według 14 szczegółowych kryteriów, a nie ze względu na wartość artystyczną czy techniczną rysunku. Przedmiotem oceny są: kontynuacje narysowanych elementów na arkuszu, uzupełnienia, nowe elementy, połączenia liniowe, powiązania tematyczne, wykorzystanie małego kwadratu poza ramą, wykroczenie poza ramę, perspektywa, humor i emocje, niekonwencjonalna manipulacja, abstrakcyjność, połączenia figuralno-symboliczne, niestereotypowość oraz szybkość wykonanego rysunku. Wysoko punktuje się wyjście poza ramę, co zdaniem autorów ukazuje gotowość do podejmowania ryzyka i zachowań nonkonformistycznych. Wynik surowy stanowi suma wszystkich punktów przyznanych za rysunek.

Autorzy testu nie dokonali szczegółowego przyporządkowania ocenianych aspektów rysunku do komponentów twórczości uwzględnionych w ich modelu teoretycznym, przyporządkowanie, z którego skorzystałyśmy $\mathrm{w}$ analizie uzyskanych w badaniach wyników, jest zasługą autorek polskiej adaptacji narzędzia.

Kwestionariusz dla rodziców i nauczycieli: Jak twórcze jest dziecko? pozwala ustalić, które obszary aktywności twórczej są bardziej, a które mniej, rozwinięte u danego dziecka (Ratajczyk, Mielcarek, 2014). Pomaga wskazać poziom pomysłowości oraz wyobraźni twórczej, ujawniającej się w codziennej aktywności dziecka w wieku przedszkolnym. Składa się z 14 pytań, które dotyczą częstotliwości różnych zachowań dziecka w sytuacjach obejmujących inicjatywę twórczą w codziennej aktywności, takich jak zabawa, prace manualne, komunikacja werbalna. Przykładowe itemy: „Dziecko samodzielnie wymyśla sobie nowe zabawy”; „Dziecko lubi «bawić się słowami» (np. wymyśla rymowanki, zagadki, pieszczotliwe określenia)”; „Dziecko buduje z klocków własne konstrukcje (buduje nie tylko według gotowej instrukcji)". Zadaniem osoby badanej jest ustosunkowanie się do twierdzeń przez zaznaczenie, które czynności 
dziecko wykonuje częściej, a które rzadziej. Częstotliwość określana jest na 5-stopniowej skali (od „,bardzo rzadko” do „,bardzo często”). Im więcej odpowiedzi potwierdzających dużą częstotliwość aktywności dziecka w różnych obszarach, tym większe natężenie twórczego myślenia w działaniu.

Kwestionariusz korzystania z urządzeń multimedialnych przez dzieci w wieku przedszkolnym, skonstruowany na potrzeby badań własnych, pozwala ustalić ilość czasu spędzanego przed ekranem urządzeń multimedialnych przez dzieci w wieku przedszkolnym, udziela informacji o rodzaju urządzeń, jakie dzieci posiadają do własnego użytku oraz w jaki sposób z nich korzystają. Kwestionariusz zawiera również pytania określone metryczką. Pytania dotyczące korzystania z urządzeń ekranowych mają trzy lub cztery możliwości odpowiedzi, z których osoba badana (rodzic/opiekun prawny dziecka) zaznacza jedną przez siebie wybraną. Przykładowe itemy:
- Ile czasu dziennie dziecko poświęca na zabawe nie korzystajac z urzadzeń ekranowych? (a) 0-0,5 h; (b) 0,5-1 h; (c) $1-2 h$; (d) $3 h$ lub więcej

- Czy dziecko oglada telewizję lub korzysta z telefonu samo czy w towarzystwie dorostego?

(a) przeważnie samo (dorosty wypetnia $w$ tym czasie obowiazki domowe)

(b) często $w$ towarzystwie dorosłego

(c) zawsze $w$ towarzystwie dorostego

- Czy dziecko ma wtasny:

(a) smartfon; (b) tablet/komputer; (c) telewizor w swoim pokoju; (d) nie ma

\section{WYNIKI}

Wyniki zaprezentowane w tabeli 2 wskazują na zgodność zmiennych „Myślenie twórcze” i „Aktywność twórcza” z rozkładem normalnym oraz brak zgodności z rozkładem normalnym

Tabela 2. Statystyczny opis zmiennych zależnych

\begin{tabular}{|l|c|c|c|c|c|c|}
\hline \multicolumn{1}{|c|}{ Zmienna } & Min & Max & $\boldsymbol{M}$ & SD & $\begin{array}{c}\text { Kolmogorow- } \\
\text {-Smirnow }\end{array}$ & $\begin{array}{c}\text { Alpha } \\
\text { Cronbacha }\end{array}$ \\
\hline Myślenie twórcze & 9 & 41 & 25.00 & 8.60 & .136 & .64 \\
\hline Kontynuacje (Kn) & 2 & 6 & 4.33 & .99 & $.315^{* *}$ & - \\
\hline Uzupełnienia (Uz) & 0 & 6 & 3.80 & 1.45 & $.196^{* *}$ & - \\
\hline Nowe elementy (Ne) & 0 & 6 & 3.50 & 2.50 & $.241^{* *}$ & - \\
\hline Połączenia liniowe (Pl) & 0 & 6 & 2.63 & 2.25 & $.199^{* *}$ & - \\
\hline Powiązania tematyczne (Pt) & 0 & 6 & 4.83 & 2.02 & $.418^{* *}$ & - \\
\hline Mały otwarty kwadracik poza ramką (Kw) & 0 & 9 & .70 & 2.18 & $.526^{* *}$ & - \\
\hline Wykroczenia poza ramę (Wr) & 0 & 6 & .70 & 1.71 & $.493^{* *}$ & - \\
\hline Perspektywa (Pe) & 0 & 1 & .03 & .18 & $.539^{* *}$ & - \\
\hline Humor i emocje (He) & 0 & 5 & 1.57 & 1.28 & $.171^{*}$ & - \\
\hline Niekonwencjonalna manipulacja (Nm) & 0 & 3 & .10 & .55 & $.539^{* *}$ & - \\
\hline Abstrakcyjność (Ab) & 0 & 3 & .70 & 1.29 & $.473^{* *}$ & - \\
\hline Połączenia figuralno-symboliczne (Fs) & 0 & 3 & .20 & .76 & $.537^{* *}$ & - \\
\hline Niestereotypowość (Ns) & 0 & 3 & 1.30 & 1.26 & $.248^{* *}$ & - \\
\hline Szybkość (Sz) & 0 & 5 & .87 & 1.38 & $.368^{* *}$ & - \\
\hline Aktywność twórcza & 36 & 61 & 47.37 & 6.57 & .090 & .73 \\
\hline
\end{tabular}

${ }^{*} p<.05,{ }^{* *} p<.01$

Źródło: opracowanie własne. 
pozostałych zmiennych, będących wymiarami „Myślenia twórczego”. Ponieważ większość zmiennych wyrażona jest na skali porządkowej, do statystycznej analizy postawionych hipotez użyto testów nieparametrycznych. Dla wyników ogólnych testu Twórczego Myślenia TCT-DP oraz testu Jak twórcze jest dziecko? wyliczono wskaźnik rzetelności Alpha Cronbacha, jego wyniki pozwalają na uznanie obydwu skal za optymalnie rzetelne. Wyniki zostały obliczone za pomocą programu SPSS Statistic 24.

Wyniki testu U Manna-Whitneya, zaprezentowane w tabeli 3 wskazują, że dzieci w wieku przedszkolnym posiadające własne urządzenie ekranowe nie różnią się istotnie od dzieci nieposiadających własnego urządzenia ani poziomem myślenia twórczego ani też poziomem aktywności twórczej.

Wyniki testu $r_{s}$-Spearmana zaprezentowane w tabeli 4 wskazują, że „Czas korzystania z urządzeń ekranowych" w dniach tygodnia po powrocie z przedszkola istotnie, ujemnie i umiarkowanie koreluje z „Myśleniem twórczym” i jego wymiarami: „Wykroczenie poza ramę”, „Niekonwencjonalna manipulacja”, „Abstrakcyjność”, „Niestereotypowość” i „Szybkość”.

Tabela 3. „Posiadanie urządzenia ekranowego” a „Myślenie twórcze” i „Aktywność twórcza”

\begin{tabular}{|c|c|c|c|c|}
\hline \multirow{3}{*}{ Zmienna } & \multicolumn{2}{|c|}{ Posiadanie urządzenia ekranowego } & \multirow{3}{*}{$\begin{array}{l}\text { U Manna- } \\
\text {-Whitneya }\end{array}$} & \multirow{3}{*}{$p$} \\
\hline & \multirow{2}{*}{$\begin{array}{c}\begin{array}{c}\text { Tak } \\
(\mathrm{n}=15)\end{array} \\
M\end{array}$} & \multirow{2}{*}{$\begin{array}{c}\begin{array}{c}\text { Nie } \\
(n=15)\end{array} \\
M\end{array}$} & & \\
\hline & & & & \\
\hline Myślenie twórcze & 13.70 & 17.30 & -1.12 & .267 \\
\hline $\mathrm{Kn}$ & 15.20 & 15.80 & -.20 & .870 \\
\hline $\mathrm{Uz}$ & 13.30 & 17.67 & -1.39 & .187 \\
\hline $\mathrm{Ne}$ & 13.07 & 17.93 & -1.58 & .137 \\
\hline Pl & 15.80 & 15.20 & -.19 & .870 \\
\hline $\mathrm{Pt}$ & 13.90 & 17.10 & -1.23 & .325 \\
\hline $\mathrm{Kw}$ & 16.03 & 14.97 & -.64 & .744 \\
\hline $\mathrm{Wr}$ & 14.10 & 16.90 & -1.34 & .389 \\
\hline $\mathrm{Pe}$ & 15.00 & 16.00 & -1.00 & .775 \\
\hline $\mathrm{He}$ & 15.00 & 16.00 & -.32 & .748 \\
\hline $\mathrm{Nm}$ & 16.00 & 15.00 & -1.00 & .317 \\
\hline $\mathrm{Ab}$ & 15.00 & 16.00 & -.42 & .671 \\
\hline Fs & 16.50 & 14.50 & -1.44 & .539 \\
\hline Ns & 16.03 & 14.97 & -.35 & .744 \\
\hline $\mathrm{Sz}$ & 14.00 & 17.00 & -1.08 & .367 \\
\hline Aktywność twórcza & 14.80 & 16.20 & -.44 & .683 \\
\hline
\end{tabular}

${ }^{*} p<.05,{ }^{* *} p<.01 ; \mathrm{Kn}$ - Kontynuacje; Uz - Uzupełnienia; Ne - Nowe elementy; Pl - Połączenia liniowe; $\mathrm{Pt}$ - Powiązania tematyczne; $\mathrm{Kw}$ - Mały otwarty kwadracik poza ramką; $\mathrm{Wr}$ - Wykroczenia poza ramę; $\mathrm{Pe}$ - Perspektywa; He - Humor i emocje; Nm - Niekonwencjonalna manipulacja; Ab - Abstrakcyjność; Fs - Połączenia figuralno-symboliczne; Ns - Niestereotypowość; Sz - Szybkość

Źródło: opracowanie własne. 
Oznacza to, że dzieci spędzające więcej czasu przy mediach ekranowych osiągają niższe wyniki na wymienionych skalach.

Czas spędzany przez dziecko przy urządzeniach ekranowych w dzień wolny koreluje istotnie, ujemnie, umiarkowanie $\mathrm{z}$,Myśleniem twórczym” i jego wymiarami: „Wykroczenie poza ramę”, „Niekonwencjonalna manipulacja”, „Połączenia figuralno-symboliczne”, „Niestereotypowość” i „Szybkość”. Oznacza to, że dzieci spędzające więcej czasu na używaniu mediów ekranowych w dniu wolnym osiągają niższe wyniki na wymienionych skalach.
Dodatkowo sprawdzono korelację pomiędzy badanymi zmiennymi a czasem, który dzieci potrafią poświęcić na zabawę bez urządzeń ekranowych. Wyniki wskazują na istotne, dodatnie umiarkowane korelacje ze zmienną „Uzupełnianie” i „Aktywność twórcza” oraz ujemny, umiarkowany związek ze zmienną „Nowe elementy”. Oznacza to, że dzieci, które są w stanie poświęcić na zabawę bez mediów ekranowych więcej czasu, osiągają wyższe wyniki na skali „Uzupełnianie” i „Aktywność twórcza”, ale gorsze wyniki na skali „Nowe elementy".

Tabela 4. „Czas korzystania z urządzeń ekranowych” a „Myślenie twórcze” i „Aktywność twórcza" - współczynniki korelacji $r_{s}$-Spearmana

\begin{tabular}{|l|c|c|c|}
\hline \multicolumn{1}{|c|}{ Zmienne } & $\begin{array}{c}\text { Czas spędzony przy } \\
\text { urządzeniach ekranowych } \\
\text { w dzień po przedszkolu }\end{array}$ & $\begin{array}{c}\text { Czas spędzony przy } \\
\text { urządzeniach ekrano- } \\
\text { wych w dzień wolny }\end{array}$ & $\begin{array}{c}\text { Czas poświęcony na } \\
\text { zabawę bez urządzeń } \\
\text { ekranowych }\end{array}$ \\
\hline Myślenie twórcze & $-.479^{* *}$ & $-.318^{*}$ & .002 \\
\hline $\mathrm{Kn}$ & -.135 & .004 & .296 \\
\hline $\mathrm{Uz}$ & -.115 & -.093 & $.436^{* *}$ \\
\hline $\mathrm{Ne}$ & .008 & .198 & $-.360^{*}$ \\
\hline $\mathrm{Pl}$ & -.211 & -.189 & -.133 \\
\hline $\mathrm{Pt}$ & -.109 & -.178 & -.079 \\
\hline $\mathrm{Kw}$ & .002 & .300 & .046 \\
\hline $\mathrm{Wr}$ & $-.374^{*}$ & $-.428^{* *}$ & -.054 \\
\hline $\mathrm{Pe}$ & -.139 & -.063 & -.089 \\
\hline $\mathrm{He}$ & -.181 & -.226 & .253 \\
\hline $\mathrm{Nm}$ & $-.313^{*}$ & $-.327^{*}$ & .266 \\
\hline $\mathrm{Ab}$ & $-.365^{*}$ & -.283 & .038 \\
\hline $\mathrm{Fs}$ & .217 & $.398^{*}$ & -.127 \\
\hline $\mathrm{Ns}$ & $-.461^{* *}$ & $-.390^{*}$ & -.051 \\
\hline $\mathrm{Sz}$ & $-.497^{* *}$ & $-.539^{* *}$ & -.011 \\
\hline $\mathrm{Aktywność} \mathrm{twórcza}$ & -.211 & -.206 & $.506^{* *}$ \\
\hline
\end{tabular}

${ }^{*} p<.05,{ }^{* *} p<.01 ;$ Kn - Kontynuacje; Uz - Uzupełnienia; Ne - Nowe elementy; Pl - Połączenia liniowe; $\mathrm{Pt}$ - Powiązania tematyczne ; Kw - Mały otwarty kwadracik poza ramką; Wr - Wykroczenia poza ramę; Pe - Perspektywa; He - Humor i emocje; Nm - Niekonwencjonalna manipulacja; Ab - Abstrakcyjność; Fs - Połączenia figuralno-symboliczne; Ns - Niestereotypowość; Sz - Szybkość

Źródło: opracowanie własne. 


\section{DYSKUSJA}

Przeprowadzone przez nas badania dotyczyły nielicznej próby osób badanych, z ostrożnością należy zatem podchodzić do uogólniania wniosków wyprowadzonych z dokonanej analizy wyników, warto jednak uwzględnić je w kontekście wyników uzyskiwanych przez innych badaczy oraz jako przyczynek do dalszych badań w tym obszarze. Uzyskane wyniki wskazują bowiem na istnienie związku między ilością czasu spędzanego przed ekranem multimedialnym przez dzieci przedszkolne a poziomem ich myślenia twórczego oraz aktywności twórczej. Badania pokazują, że długość czasu wolnego, który dziecko spędza po powrocie z przedszkola, korzystając z urządzeń ekranowych, koreluje ujemnie $\mathrm{z}$ myśleniem twórczym oraz jego poszczególnymi wymiarami. Pierwszy wymiar to „Wykroczenie poza ramę”, które wskazuje na nonkonformizm oraz gotowość do podejmowania ryzyka. Innymi słowy dzieci, które uzyskały wyższe wyniki w obszarze tego wymiaru, są bardziej skłonne do działań według własnego kierunku myślenia, mają odwagę bronić własnych przekonań i potrafią stanąć w opozycji do poglądów innych ludzi, częściej niż dzieci o niskich wynikach na tym wymiarze. Kolejną składową „Myślenia twórczego”, której wartość wzrasta przy jednoczesnym spadku ilości czasu spędzanego przy mediach ekranowych, jest „Niekonwencjonalna manipulacja” mieszcząca się w wymienionym przez Urbana (2005) kryterium, jakim jest „Oryginalność”, czyli szukanie pomysłów, które są nietypowe, odkrywcze, bądź dziwne, niespotykane. Dziecko, które nie przesiaduje całymi popołudniami przed telewizorem czy tabletem, generuje więcej ciekawych pomysłów i łatwiej jest mu zapełnić swój wolny czas swobodną zabawą niż wpatrywaniem się w ekran. „Abstrakcyjność” to kolejny wymiar, który ma związek z czasem spędzanym przez dziecko po przedszkolu przy multimediach. Wysoka punktacja, która zależała od symbolicznej wymowy rysunku lub wprowadzenia do niego elementów surrealistycznych bądź fikcyjnych, przyznawana była za twórczą wyobraźnię dziecka. Wyobraźnia, jako pewna właściwość umysłu, „stanowi podstawę zarówno reprodukcyjnej aktywności umysłu, czyli pamięci, jak i aktywności kombinatorycznej-myślenia" (Kubicka, 2007b, s. 163). Według Jeana Piageta (1981; 2006) wyobraźnia rozwija się wskutek aktywnego działania, co oznacza, że dziecko łatwiej wyobraża sobie różne sytuacje czy przedmioty, jeśli w pierwszej kolejności wykonuje z nimi rozmaite czynności: obserwuje je, wypowiada się o nich, eksploruje, analizuje i przekształca na różne sposoby. Można zatem powiedzieć, że czynności związane z korzystaniem z urządzeń ekranowych, w których sam obraz i dźwięk nie daje możliwości wejścia w interakcję bądź rozmowy o tym, co dziecko widzi na ekranie, czy też podjęcia aktywności w związku z przekazem multimedialnym, nie rozwijają wyobraźni dziecka. Wyniki badań własnych, które ukazują negatywny związek między ilością czasu korzystania z urządzeń ekranowych a wyobraźnią dziecka, znajdują potwierdzenie również w literaturze. Badania Patti M. Valkenburg i Johannesa W.J. Beentjesa (1997) ujawniły, że tendencja do wymyślania twórczych rozwiązań była większa w grupie, w której prezentowane były treści audialne, niż w grupie, która oglądała treści audiowizualne. Oznacza to, że dzieci, które oglądają przekazy audiowizualne na ekranie telewizora, na smartfonie czy tablecie, mają mniejszą potrzebę do wytwarzania nowych treści i ograniczają się do kopiowania i odwzorowywania tego, co widziały. Zjawisko to często można zaobserwować u bawiących się dzieci, które wcielają się w rolę bohaterów z bajek, wiernie odgrywając zapamiętane sceny, bardziej na zasadzie kopiowania, imitowania niż kreowania roli danego bohatera. Oczywiście oglądane bajki mogą być inspiracją do zabawy „na niby” (symbolicznej) oraz dostarczać bogatego materiału dla wyobraźni. Wtedy miarą myślenia twórczego w zabawie jest rozwinięcie aktywności zabawowej o nowatorskie pomysły i wątki, które nie wystąpiły w materiale bodźcowym. Kolejne wymiary, które korelują z ilością czasu spędzanego na korzystaniu z mediów ekranowych, to: „Niestereotypowość” i „Szybkość”. Pierwszy z nich jest wyznacznikiem oryginalności, o której mowa była powyżej. „Szybkość” natomiast oznacza płynność w myśleniu twórczym, czyli zdolność podawania jak największej liczby po- 
mysłów oraz łatwość ich wytwarzania (Nęcka, 2001, s. 27). Dziecko potrafi generować wiele pomysłów i poszukiwać właściwego rozwiązania. Jest to przejaw myślenia dywergencyjnego, które stanowi warunek, a także zapowiedź, twórczych predyspozycji. Każda sytuacja, w której dziecko się znajduje, może być stymulatorem do wykorzystania różnych sposobów myślenia. Dywergencyjność zatem daje dziecku szansę wyboru i, w zależności od poziomu myślenia twórczego, wiele różnych dróg i alternatyw postrzegania i interpretowania własnych doświadczeń oraz poszukiwania możliwych rozwiązań (standardowych, ale także bardzo nietypowych).

Badania wykazały również istotne korelacje ujemne czasu spędzanego przy mediach ekranowych w dzień wolny od przedszkola $\mathrm{z}$ myśleniem twórczym i jego wymiarami. Te wymiary to: „Wykroczenia poza ramę”, „Niekonwencjonalna manipulacja”, „Niestereotypowość", „Szybkość” oraz „Połączenia figuralno-symboliczne", które nie pojawiły się wśród korelacji $\mathrm{z}$ „Czasem korzystania z urządzeń ekranowych” w dniach po przedszkolu. Wysokie wyniki na wymiarze „Połączenia figuralno-symboliczne” uzyskane przez dziecko, oznaczają pewną zdolność wytwarzania produktów poznawczych, inaczej mówiąc, zdolność operacji na pewnych treściach obejmujących informacje i ich zrozumienie. Myślenie symboliczne jest myśleniem w kategoriach analizy i syntezy oraz pewnego rodzaju analogii, którą dziecko przekazuje za pomocą znaków symbolicznych (Dołęga, 1991). Może oznaczać to, że dzieci, które więcej czasu spędzają na korzystaniu z urządzeń ekranowych mają mniejsze zdolności rozumowania i wyrażania swoich myśli niewerbalnie niż dzieci, które korzystają z nich mniej, i potrafią wyrazić swoje odczucia poprzez analogię symboli czy znaków graficznych.

Co więcej, w badaniach własnych sprawdzono związki między natężeniem myślenia twórczego i aktywności twórczej a czasem poświęcanym przez dzieci przedszkolne na swobodną zabawę, wyłączając korzystanie z urządzeń ekranowych. Analiza wyników wskazała na istotne, dodatnie korelacje $\mathrm{z}$ wymiarem myślenia twórczego, jakim jest „Uzupełnianie”, oraz z „Aktywnością twórczą". Punkty uzyskane przez dzieci na wy- miarze „Uzupełnienia” oznaczają zdolność do elaboracji, czyli opracowywania istniejącego materiału przez dodawanie czegoś nowego, tworzenie nowej, oryginalnej wersji. W teście polegało to na uzupełnianiu narysowanych wcześniej elementów, rozbudowaniu ich lub domknięciu. Można wysunąć wniosek, że dziecko poświęcające więcej czasu dziennie na swobodną zabawę, ma większe szanse na opracowywanie nowych doświadczeń i informacji, oraz modyfikowanie ich w postaci nowych wytworów. Dziecko poddawane dużej ilości bodźców przez dłuższy czas, płynących z urządzenia ekranowego, nie ma możliwości, a przede wszystkim czasu na weryfikację oglądanych treści i odniesienie ich do własnych doświadczeń. W badaniu uzyskano również dodatnią korelację między „Czasem w zabawie” a zmienną „Aktywność twórcza”, co wskazuje, że dzieci, które częściej bawią się bez korzystania z urządzeń ekranowych, wykazują większą zdolność twórczego działania, przejawiającą się w podstawowych formach działalności dziecka w tym okresie: zabawie, aktywności plastycznej oraz językowej. Korelacje ukazały również ujemny związek między „Czasem poświęcanym na zabawę” a wymiarem myślenia twórczego: „Nowe elementy”. Znaczy to, że dzieci, które dłużej bawią się poza multimediami, uzyskały gorsze wyniki w zadaniu, które polegało na dorysowaniu nowych elementów, co wiąże się z płynnością myślenia, a co za tym idzie, z szybkością wytwarzania pomysłów. Powodów uzyskania takich wyników może być kilka. Po pierwsze, elementy dorysowane mogły być wielokrotnością jednego pomysłu, które narysowane w nieco innej formie zaliczały się do pełnej punktacji, po drugie dzieci bawiące się bez urządzeń ekranowych mają czas do namysłu i interpretacji własnych pomysłów lub inspiracji z zewnątrz, natomiast dzieci często korzystające $\mathrm{z}$ multimediów dostają gotowy produkt natychmiast, co próbowały powtórzyć w zadaniu, nie zastanawiając się nad syntezą i holistycznym podejściem do niego. Można snuć rozważania, czy dla dzieci w tym wieku zadanie nie jest zbyt trudne, lecz analiza prac pokazuje, że jest wiele rysunków, które tworzą spójną całość, co często potwierdza tytuł nadany przez małego autora. Wreszcie innym powodem może być pozytywny 
wpływ korzystania z urządzeń elektronicznych, co może być źródłem inspiracji dla wyobraźni, dostarczając wizualnych bodźców do tworzenia wyobrażeń. Jeśli oglądanie bajek czy programów odbywa się w towarzystwie dorosłego, a treści są dobierane i omawiane przez rodzica, to śmiało można założyć, że tak właśnie jest. Taka hipoteza inspiruje do podejmowania kolejnych badań, które przeprowadzone $\mathrm{z}$ udziałem odpowiednio licznej grupy dzieci w okresie przedszkolnym mogą rozwiać wiele wątpliwości.

Warto jeszcze wspomnieć o hipotezie dotyczącej różnic w zależności od korzystania z konkretnego urządzenia w grupie dzieci przedszkolnych. Wyniki analizy wskazały, że dzieci korzystające ze smartfonu częściej wykraczają poza ramę w Rysunkowym Teście Twórczego Myślenia niż dzieci korzystające z telewizora, komputera i tabletu. Uzyskane wyniki mogą oznaczać, że dzieci, które częściej korzystają ze smartfonu, są bardziej aktywne, na przykład podczas gier lub samej obsługi urządzenia. Używanie smartfonu wymaga pewnego działania, eksploracji, poznawania nowych funkcji i możliwości, jakie daje to urządzenie. Telewizor natomiast nie wymaga takich aktywności, poza włączeniem i patrzeniem na ekran. Obszar ten wart jest dalszych badań dotyczących różnic między skutkami używania różnych urządzeń ekranowych przez dzieci, być może niesłusz- nie w wielu projektach badawczych wszystkie urządzenia umieszczane są w jednej kategorii.

Podsumowując uzyskane wyniki, można stwierdzić, że dla poziomu myślenia twórczego najistotniejsze znaczenie ma czas spędzany przez dziecko przed ekranem (screen time). Zbyt częste i zbyt długie korzystanie przez dzieci z urządzeń ekranowych generuje niekorzystne rezultaty dla zdrowia i rozwoju dzieci, wprowadzając je na drogę mogącą skutkować uzależnieniem (por. Twenge, Martin, Campbell, 2018). Warto w tym miejscu podkreślić, że dzieci w wieku przedszkolnym nie są jeszcze zdolne do samoograniczenia, dlatego nie do przecenienia jest tu rola dorosłych opiekunów, którzy wprowadzają dziecko w świat multimediów i uczą reguł korzystania z nich, tak, aby były one ubogacające, ułatwiające życie, a nie zabierające i ograniczające to życie w przyszłości (por. Troseth, Strouse, Johnson, 2018). W tej perspektywie optymizmem nie napawają niestety uzyskane przez nas wyniki pokazujące, że około $30 \%$ badanych dzieci w wieku 5-7 lat ma telewizor we własnym pokoju, ponad $23 \%$ ma w tym wieku już własny tablet, a prawie co drugie badane dziecko $(46,7 \%)$ korzysta z urządzeń ekranowych przeważnie samo (zob. tab. 1). Uzyskane wyniki skłaniają do objęcia szczególną uważnością roli dorosłych opiekunów w procesie nauki korzystania $\mathrm{z}$ mediów ekranowych przez dzieci.

\section{BIBLIOGRAFIA}

Appelt K. (2009), O rozwoju kompetencji w świecie współczesnym szczególnie potrzebnej. Polonistyka, 4(464), 53-57.

Appelt K. (2015), Kontekstowe uwarunkowania jakości społecznego środowiska rozwoju małych dzieci w Polsce. Polskie Forum Psychologiczne, 3(20), 358-379.

Booker C.L., Kelly Y.J. Sacker A. (2018), Gender differences in the associations between age trends of social media interaction and well-being among 10-15 year olds in the UK. BMC Public Health.

Brzezińska A.I., Appelt K., Ziółkowska B. (2016). Psychologia rozwoju człowieka. Gdańsk: Gdańskie Wydawnictwo Psychologiczne.

Chassiakos Y.R., Radesky J., Christakis D., Moreno M.A., Cross C. (2016), Children and Adolescents and Digital Media. Pediatrics, 138(5), e20162593.

Celis-Morales C.A., Lyall D.M., Steell L., Gray S.R., Iliodromiti S., Anderson J., Mackay D.F., Welsh P., Yates T., Pell J.P., Sattar N., Gill J.M.R. (2018), Associations of discretionary screen time with mortality, cardiovascular disease and cancer are attenuated by strength, fitness and physical activity: Findings from the UK Biobank study. BMC Medicine, 1-14.

Dołęga J.M. (1991), Znak-język-symbol. Z podstawowych zagadnień komunikacji. Warszawa: Akademia Teologii Katolickiej. 
Granic I., Lobel A., Engels R.C.M.E. (2013), The benefits of playing video games. American Psychologist, $1(69), 66-78$.

Jarzembowska M. (2018). Myślenie i aktywność twórcza a korzystanie z multimediów przez dzieci w okresie przedszkolnym. Niepublikowany maszynopis pracy magisterskiej. Poznań: Instytut Psychologii UAM.

Kubicka D. (2007a), Badania nad wpływem telewizji na dzieci, młodzież i dorosłych. W: D. Kubicka, A. Kołodziejczyk (red.), Psychologia wplywu mediów. Wybrane teorie, metody, badania, 115-143. Kraków: Oficyna Wydawnicza Impuls.

Kubicka D. (2007b), Telewizja a twórcza wyobraźnia dziecka. W: D. Kubicka, A. Kołodziejczyk (red.), Psychologia wpływu mediów. Wybrane teorie, metody, badania, 163-185. Kraków: Oficyna Wydawnicza Impuls.

Le Bourgeois M.K., Hale L., Chang A.M., Akacem L.D., Montgomery-Downs H.E., Buxton O.M. (2017), Digital Media and Sleep in Childhood and Adolescence. Pediatrics, 140(2), e20161758.

Matczak A., Jaworowska A., Stańczak J. (2000), Rysunkowy Test Twórczego Myślenia K.K. Urbana i H.G. Jellena. Podręcznik. Warszawa: Pracownia Testów Psychologicznych PTP.

Mullan K. (2017), Technology and Children's Screen-Based Activities in the UK: The Story of the Millennium So Far. Child Indicators Research, 11(6), 1781-1800.

Nęcka E. (2001), Psychologia twórczości. Gdańsk: Gdańskie Wydawnictwo Psychologiczne.

Pagani L.S., Lévesque-Seck F., Fitzpatrick C. (2016), Prospective associations between televiewing at toddlerhood and later self-reported social impairment at middle school in a Canadian longitudinal cohort born in 1997/1998. Psychological Medicine, 46 3329-3337.

Peper E., Harvey R. (2018), Digital Addiction: Increased Loneliness, Anxiety, and Depression. NeuroRegulation, 5(1), 3-8.

Piaget J. (1981), Intelligence and affectivity: Their relationship during child development. Palo Alto, CA: Annual Review, Inc.

Piaget J. (2006), Studia z psychologii dziecka. Warszawa: Wydawnictwo Naukowe PWN.

Przybylski A.K. (2014), Electronic Gaming and Psychosocial Adjustment. Pediatrics, 134(3), 1-7.

Przybylski A.K., Deci E.L., Rigby C.S., Ryan R.M. (2014), Competence-impeding electronic games and players' aggressive feelings, thoughts, and behaviors. Journal of Personality and Social Psychology, 106 (3), 441-457.

Przybylski A.K., Weinstein N., Murayama K. (2016), Internet Gaming Disorder: Investigating the Clinical Relevance of a New Phenomenon. American Journal of Psychiatry, 1-7.

Przybysz-Zaremba M. (2008), Uzależnienie młodzieży od współczesnych mediów. Olsztyn: Oficyna Wydawnicza Prospekt.

Radesky J.S., Kistin C., Eisenberg S., Gross J., Block G., Zuckerman B., Silverstein M. (2016), Parent Perspectives on Their Mobile Technology Use. Journal of Developmental \& Behavioral Pediatrics.

Ratajczyk A., Mielcarek M. (2014), Monitorowanie rozwoju w okresie dzieciństwa i dorastania. Tom 2. Seria IV: Niezbędnik Dobrego Nauczyciela (red. A. I. Brzezińska). Warszawa: Instytut Badań Edukacyjnych.

Simonato I., Janosz M., Archambault I., Pagani L.S. (2018), Prospective associations between toddler televiewing and subsequent lifestyle habits in adolescence. Preventive Medicine, 110(5), 24-30.

Szpunar M. (2004), Społeczności wirtualne jako społeczności - próba ujęcia socjologicznego. W: M. Radochoński, B. Przywara (red.), Jednostka, grupa, cybersieć. Psychologiczne, społeczno-kulturowe i edukacyjne aspekty społeczeństwa informacyjnego, 157-184. Rzeszów: Wyższa Szkoła Informatyki i Zarządzania,.

Troseth G.L., Strouse G.A., Johnson C.E.R. (2018), Early Digital Literacy: Learning to Watch, Watching to Learn. W: F.C. Blumberg, P.J. Brooks (red.), Cognitive Development in Digital Contexts, 29-51. Cambridge, MA:Academic Press.

Twenge J.M., Martin G.N., Campbell W.K., (2018), Decreases in Psychological Well-Being Among American Adolescents After 2012 and Links to Screen Time During the Rise of Smartphone Technology. Emotion, 18(6), 765-780.

Urban K.K. (1991), On the development of creativity in children. Creativity Research Journal, 4, 177-191.

Urban K.K. (2005), Assessing creativity: The Test for Creative Thinking - Drawing Production (TCT-DP). International Education Journal, 6(2), 272-280.

Urban K.K., Jellen H.G. (1996), Test for Creative Thinking - Drawing Production (TCT-DP). Lisse, Netherlands: Swets and Zeitlinger.

Vankelburg P.M., Beentjes J.W.J. (1997), Children's Creative Imagination in Response to Radio and Television Stories. Journal of Communication, 47(2), 21-38. 